\title{
CHAPTER FIVE
}

\section{TRAJECTORIES OF RELIGIOUS ACTS AND DESIRES: BARGAINING WITH RELIGIOUS NORMS AND IDEALS}

Do not ask who I am and do not ask me to remain the same: leave it to our bureaucrats and our police to see that our papers are in order. At least spare us their morality when we write.

-Foucault 2006 [1969], 19

I am walking in Kreuzberg on a cold October afternoon, searching for VICUM hall, a popular, Turkish-owned venue for weddings and religious events. Today, MJD and other German-speaking Muslim organizations such as DMK, are organizing a large Aquiqua celebration. ${ }^{1}$ Finally, I see the "VICUM" neon sign on a tall brick building, and several men standing outside chatting. As I enter, I pass the many baby carriers in the entrance, and go up the stairs noticing women and children walking up in front of me. A young boy, perhaps around ten years old, asks if he can help me find what I am looking for. When I tell him: "I'm fine, thank you," he insists: "Who are you looking for?" Since I am not really looking for anyone in particular, I shrug my head and say, "Noreen," after which he leaves me alone. Maybe I simply looked lost, but my sense is that he perceived me to be in the wrong place, as I am not wearing a headscarf and clearly have no discernible Arab or Turkish background.

I leave my shoes by the entrance before entering the first room filled with men. In the right hand corner, there are several prayer rugs on the floor and a few men are praying. There are more than 400 people in the large main room, where the space is divided along gendered lines: the men on the right, and the women and children on the left. I later notice that when the common prayer is performed, the division of the room makes it possible for the women to pray behind the men. Not everyone wears the headscarf, and I also see some I believe to be ethnic Germans sitting at a table, wearing jeans and waist-long sweaters. In the main room, Noreen (16) greets me, asking: "Did you hear my father speak?" I tell her that I am sorry to have missed him, as I had difficulties finding the place. "Is there a program?" a girl asks. Some of the other girls complain about poor organization: "It's all a bit confusing!"

I am told that they are celebrating nine newborns. Sevda (25) explains that they have to slaughter two sheep for each boy and one for each girl. Today, fourteen sheep were slaughtered. "So much was thrown away, haram!" Sevda tells me. "But we didn't have enough time to give it away. Afterwards so much

1 This celebration marks the arrival of a newborn child. 
was thrown away!" She looks annoyed at the thought. Janna (19) is walking around, serving the food. I try to help her, but quickly give up as I find it confusing and am anxious about making a mistake. We are busy eating mutton and rice with raisins, when one of the girls exclaims, "hey, there are insects in the food!" It turns out to be just a spice. A few of the young girls wrinkle their noses, they are not that happy with the food. "I don't like the food," Sevda exclaims. "They always make Pakistani food at these events. I don't know why." Reflecting further, she continues, "why do Egyptians and Turks make Pakistani food? They must have had it made by someone else." Afterwards, I stand in a group of four young girls telling jokes. "What does a blonde say after sex?" one asks, pausing before delivering the punch line, "do you all play on the same football team?" Naila (17) tells the next joke. "Why is a blonde standing at a bus stop with a mattress? She is going to an interview and they asked her to bring her 'supporting layer' (Unterlage)." ${ }^{2}$ One of the girls laughs audibly and is quickly hushed by the others, who are constantly looking around to see if anyone is approaching. "Wait!" is uttered through the group every time an older woman comes within earshot. Another girl, Saad (16), joins us and Rezan (18) asks Naila to repeat the joke. Naila is reluctant. "I don't know her, whether she will like that sort of joke." Rezan insists, "No, she is like us, tell her!" After Naila has told the joke, Saad does not laugh and it is clear that she disapproves. Naila turns to Rezan, embarrassed and worried, "Now you see, she doesn't like it! Now what is she going to think of me?" The group stops telling jokes and chats about other subjects instead. I walk over to Noreen who tells me that she is not coming to DMK the next day (Friday) because her parents have invited the entire family in their home. Aishegül (31), joining the conversations, says that her whole family is also gathering. She explains that she has a large family in Berlin, but having them nearby is not always a good thing. She often disagrees with her family members, and it is stressful to have everyone in such close proximity. During the sugar-celebration (Eid ul-Fitr), Aishegül continues, all the men walk from home to home. ${ }^{3}$ The tradition is for the men to visit everyone in the course of the evening, so they only stay in each home for fifteen to twenty minutes. The women, meanwhile, organize the food and drinks. Since MJD started to celebrate Eid ul-Fitr together, Aishegül does not celebrate it at home any more, since she "doesn't like the Turkish tradition."

Turning to the table filled with gifts, Noreen shows me that the floor under the table is also covered with wrapped presents. Usually people give money, she explains, "like, it is tradition to put money in the baby carriage. But now we have, like, become modern, and so we give presents - some people like to buy something which they can then see on the baby afterwards." Slowly, people leave the venue to pray in another mosque. Janna wonders whether to stay or go to the mosque for the prayer. In the end, she decides to stay

2 The German word Unterlage means both "documents" and something to sleep on.

3 Eid ul-Fitr is the celebration of the breaking of the fasting period, also called the sugar celebration (Zuckerfest) by Turkish migrants in Germany. 
since it is cozy now that many have left. A man calls for prayer (adhan) and some hurry to the toilets to do wudu' The prayer starts, the women find their places, and the children are left with the women who are not praying or to run around. When the event is finished, a young woman complains that people were talking too loudly while they were praying. Passing the room in front of the main room, we notice that it is filled with cigarette smoke and someone is drinking alcohol. A girl comments, "it's like a bar here." On my arrival, I had noticed that many men in the bar were smoking, which had also surprised me. It turns out that a "Turkish" wedding is taking place in the room next door. There are many people and cigarette smoke is drifting in from the other room. Sevda remarks, "not a lot of people though (given that it is a Turkish wedding)." Sevda's sister (14) adds, "hmm, what a marriage celebration. (...) I would never marry like that!"

As this event illustrates, the youth experience religious meetings and happenings very differently. During this particular event, some found it chaotic or were bored, some spent their time talking to family or friends, and others helped organize it. For Aishegül, it represented a space that was more religiously correct than the performance of the celebration held by her own family in Berlin. For Razan and Naila, it was a place to perform religious practice, but also to have fun. It was the first time I became aware that youth make great efforts to keep their incorrect behavior hidden from view. Good young Muslim women are not supposed to tell sexual jokes during religious events, yet this still occurs. The group of youth tried to hide their jokes from members of their faith community, knowing that most guests would find it inappropriate, an assumption that was confirmed by Saad's obvious disapproval of the joke.

This episode illustrates at least two sets of issues: first, as partly discussed in chapter 3 , youth sometimes tried to hide actions they believed to be religiously "incorrect" within a social space that imposes particular expectations on their behavior. Indeed, nurturing and learning religious norms includes realizing what is not right, and brings a set of obligations along with it. ${ }^{4}$ Following Bourdieu (1990), the entry into a social field brings with it a tacit recognition of the rules of the game, which means the legitimation of certain forms of struggle and the exclusion of others. Second, the youth did not conform consistently or blindly to the ideals given to them. The crafting of the religious subject or Self is not a linear or homogeneous process within a group. The problem is not a lack of knowledge about the correct standards of behavior, but rather the inability to

${ }^{4}$ Knowing a rule is to implicitly recognize what one is expected to do in specific situations; rules are broadly used and sanctioned (Giddens 1984). 
live up to these standards in practice. The youth cultivated a variety of desires and aspirations that were not only guided by Islam. They had to relate to a range of rhetoric and ideas about right and wrong, which sometimes produced tensions between different expectations and yearnings. In daily life, the youth related not only to the religious ideals and desires, but also to secular ideals from their school and peers, or to cultural ideas from their parents and their ethnic social field. This endeavor, namely the effort to mediate between religious obligations or expectations and nonreligious yearnings that diverge from them, has frequently been perceived as youth picking and choosing the parts of Islam that best suits them and their social context (see introduction). Such perceptions of Muslim youths' religious identity, I argue, neglect the complex epistemological underpinning of the youths' decisions about which norms to adhere to and which to reject and at what time and place.

My aim in this chapter is to illustrate how crafting a religious Self takes place in negotiation with a variety of desires and through individual creativity. As discussed in chapter 4, the religious doctrines and norms comprise discursive structures that the youth are expected to adopt and embody. The contexts and structures of communication establish obligations and rights regarding what youth should do as particular religious subjects. However, as Cohen recognizes, "they do not determine substantively what he or she will do within these limits" (Cohen 1994, 50). The youths' actions and practices do not merely repeat pre-determined cultural conditions. We cannot understand how these young people are crafting a religious Self merely by looking at pre-established religious doctrines and norms. Rather, the religious rules provide a mindset and knowledge in the relation to which the individual then takes action. In the process of acting out these rules and norms, they are also given meaning and direction. Consequently, in order to understand the crafting of the subject, it is not sufficient to look at established ideals, or to assume that youth respond to the religious framework as individual selective consumers or as random and increasingly secularized actors.

As an anthropologist, I am interested in the way social actors relate to and experience religious doctrines and theology in different social contexts. This chapter looks at the ways in which youth deal with how their conduct is measured and judged within their religious social field. I want to draw attention to how the young women understand and negotiate moral standards and how they deal with the impossibility of fulfilling these ideals. What is the scope available to them for forming, styling, and negotiating a religious Self within their religious social field? How are 
these youth expressing agency in both reproducing and negotiating Islam in their daily life? How can young women pursue personal desires that fall outside or are in contradiction with religious doctrine without at the same time feeling that they are failing in their efforts at becoming Good Muslims?

First, I discuss what I mean by religious trajectories in this context and in relation to Islam as a discursive tradition. Second, I trace different trajectories of religious acts, behaviors, and desires in order to demonstrate that even if the performance of religious ideals is not a homogeneous or uniform process, youth nevertheless do not relate to Islamic norms randomly. Improving one's behavior and gaining more knowledge is part of the effort of constructing oneself as a particular religious subject. ${ }^{5}$ The actions that are thinkable within a social field are relatively unpredictable, and a potentially infinite number of patterns of behavior, thoughts, and expressions are possible, but at the same time their diversity is limited. What is at stake here is understanding the creativity involved in the crafting of the religious Self, without losing sight of the existing strictures that the youth continuously relate to. Overall, I argue that the behavior or desires of an individual need to be situated within a particular religious rhetoric or structure of knowledge in order to be accepted-by the youth and their faith community—as a religious performance, desire, or behavior.

\section{Defining Religious Agency}

\section{Situating Social Behavior in a Discursive Tradition}

As discussed in the introductory chapter, this book uses Asad's concept of Islam as a discursive tradition. Conceiving of Islam as a discursive tradition includes acknowledging that the performance of Islam is not static or standardized across time and space, without at the same time dismissing the idea of a singular Islam. What is considered correct and incorrect

5 Researching Muslim youth in Germany, Lale Yalçin-Heckmann $(1998,171)$ found that whereas a significant number of youth valued Islamic teaching for the sake of the knowledge that is transmitted, many considered the knowledge as a precondition for belief and essential in their life. Others relied upon it to position themselves within the social world, as it was important for the individual's identity within the ethnic community. I did not find the latter to apply within this group of Muslim youth where religious knowledge to a large extent become a way out of the ethnic social field and stigma attached to the ethnic group (see chapter 6). The difference may relate to the fact that I focus on youth who participate 
Islamic practices and knowledge is frequently a topic of discussion among individuals, between religious authorities, and between Islamic organizations and faith communities. Orthodoxy, "a distinctive relationship - a relationship of power" (Asad 1986, 15), exists "[w]herever Muslims have the power to regulate, uphold, require, or adjust correct practices, and to condemn, exclude, undermine, or replace incorrect ones" (ibid.). Asad emphasizes that the orthodoxy of an activity or belief may be a topic of discussion. As such, orthodoxy is an effect of power struggles and may be continuously subject to reinterpretations and modifications.

The similarity of Asad's perception of orthodoxy and Foucault's idea of discursive practice is worth noting. Discourse, according to Foucault (1980, 2006 [1969]), enables and limits what can be said. Whether speech is considered legible or not is marked by discursive practices. ${ }^{6}$ Discursive practices, Foucault argues, are the localized socio-historical material conditions through which speech acts (i.e. writing, speaking, thinking, scheming, measuring, and concentrating) are both made feasible and constrained. These localized socio-historical material conditions are not transcendental or phenomenological, ahistorical conditions, but are historically situated. "Subjects" and "objects" of knowledge are produced by discursive practices, and discursive practices also determine which narrations are recognized as meaningful. The possibilities for meaningful statements are not static, but form a dynamic and contingent multiplicity (Barad 2003, 819).

\section{Positioning Behavior as Religious}

The religious discourse taught within the space of the youths' faith community shapes what is considered possible, correct, or legitimate among the adolescents. A religious discourse is not static or singular, but is subject to contestations. However, although the religious discourse is dynamic and situated in a socio-historical process, its legitimating force in the present depends upon how an individual conceptualizes the current practice in the context of the past (when its purpose and form was instituted) and the future (how and why the purpose of a practice should be maintained or modified) (Asad 1986). ${ }^{7}$ In the process of crafting a Self, these young

\footnotetext{
in a multicultural religious organization. Most participants view knowledge of Islam as a way to change their behavior and conduct, such as learning to control one's Nafs (ego).

6 The statements that can be made are part of a changing and dynamic, yet conditional multiplicity (Barad 2003, 813).

7 Thus, I do not believe we should talk of several Islams as Khosrokhavar $(1997,23)$ argues or to get rid of the analytical category Islam altogether, as el-Zein (1977) suggests.
} 
people do not merely conform to or replicate religious discursive practices. In their daily life, youth partake in different social fields and embrace different desires and aspirations. Second-generation migrants act in the German society through kindergarten, school, and work, where they often develop better socio-cultural competence than their parents. This cultural competence involves having access to more than one set of values, codes of conduct, languages, and knowledges. In other words, their subject positions are informed by multiple ways of relating to the Self. These discursive legacies include religious and secular modes of subjectivity. Consequently, youth have to relate to incompatible discourses or different modes of subjectification on an everyday basis. Abu-Lughod (1986) similarly recognizes that there are always several, often incompatible, discourses at play. At the same time, she argues against the notion of one dominant ideology that sets limits to the "thinkable and the unthinkable" (Abu-Lughod 1986, 256). Although I share her skepticism of the totalizing power of discourse, I argue that people tend to position their accounts or actions vis-à-vis the dominant discourse of the social field within which they are seeking to situate themselves.

The youths' behavior is also inconsistent, inasmuch as it does not correspond to apt performances as determined by orthodoxy (Asad 1986, 15). I found that to deal with tensions that arise between religious ideals, on the one hand, and improper or irreligious behavior or feelings of inadequacy on the other, youth legitimate their behavior by relying on certain modes of argumentation. By investigating how religious action is explained and justified, we can better understand how religiously defined acts and behaviors are creative, while simultaneously being shaped by orthodoxy.

As I will show, in order to legitimate their actions, youth are prepared to explain why they make certain choices (concerning clothing, food or body comportment). I understand the youths' practice of explaining and justifying their actions as an effort to present themselves as particular religious subjects, both to socially relevant others (such as members of the group) and in relation to their own Selves. Within the religious social field, most wish to be considered (by themselves and socially relevant others) as Good Muslims, generally defined by the extent to which they either conform to or diverge from the rules of orthodoxy. The following story illustrates the internal struggle to desire to act in concurrence with norms and the reality of lived behavior:

At a gender-divided wedding the women and girls were dancing, some without their headscarves and wearing short-sleeved tops. Suddenly, women put on their headscarves as the groom and his male family members announced 
their entrance to the female section of the wedding. I was with a group of youth who already had their headscarves on and we continued to dance. Noticing that no one else was dancing, Janna (19) suddenly took the hands of her younger sister Noor (16), her friend Alesha (15), and me, stopping our dance. She was upset, saying, "I told you we shouldn't have danced. It is haram!" I asked, "what do you mean?" Janna explained, "we shouldn't dance when the men are here, like move our hips like that, it is [not good]. Some women were looking at us, and are now saying 'that family'... like, as if everyone from our family are like that."

Janna was upset both because she felt that she was doing something religiously wrong and because of the unwanted attention others paid to our haram behavior. When Janna stopped our dancing, her argument combined religious references to haram and halal, as well as concern regarding what socially relevant others would think of her and her family. Her last comment points towards the importance of avoiding a negative reputation within the religious and ethnic social sphere, as discussed in chapter 3. Here, correct appearance in the public becomes important to protect both her own reputation as well as that of her family.

Another episode that I first found puzzling entailed a short encounter on the street with a German convert, Nadia (32), during Ramadan:

As I walked towards Nadia on the street, I saw that she was trying to hide that she was eating, which I commented on. She explained that since it was not yet iftar (the breaking of the fast for that day) she concealed her eating. In her words, "because otherwise the older men look so funny at me," even though she was menstruating and thus religiously exempt from fasting.

Although this might be a strategy to hide that she is menstruating, my impression is that Nadia's main concern was to avoid socially relevant others believing that she was acting in a religiously incorrect manner. This tactic (see chapter 3 ) exemplifies the felt necessity of situating one's actions in relation to correct religious behavior. When the religious subject is acting within a religious social field where she or he is being measured by socially relevant others vis-à-vis certain standards defined by both normative and explicit rules, the subject struggles with both performing and becoming a "correct" Muslim. Through these different heterogeneous processes and practices, the youth start to relate to each other and to themselves as particular kinds of subjects.

\section{The Religious Subject}

Crafting the Self religiously is about being a Good Muslim. Yet the crafting of the Self takes place within social fields, and involves a continuous 
negotiation between how the individual understands herself, how she wants others to see her, and how others react to her in social interactions. Subjects do not make themselves on their own. Subjects seek to be known and recognized, but always through others (Jenkins 1996), which is why the youths' religious actions cannot be chosen or performed at random. ${ }^{8}$

The youths' desire to craft themselves as correct religious subjects must be understood in relation to personal religious motivations (see chapter 7). Yet as social actors, many of these youth were also concerned with how they were perceived by their social surroundings, in particular by members of their faith community. Participating in a faith community brings with it both security, in terms of group belonging, as well as obligations regarding one's religious behavior.

In the process of crafting a religious Self, the interpretation of the Koran provides guidelines for action or a moral compass for the youth in their daily life. The ultimate aspiration is to completely master the Self by acquiring a state of being which stays on the "straight path," meaning that one pursues the norms, values, and morals provided by Islam in all aspects of life. I see the youths' behavior and desires as having to be situated in relation to a specific religious discourse in order to be considered (by herself and socially relevant others) as a particular religious subject and as someone knowledgeable about Islam.

Although the youth situated their actions in relation to the religious discourse taught in MJD, this should not lead us to imagine a homogenous performance of religious norms and ideals. Rather, acts that are considered religiously correct or apt may take a variety of forms. ${ }^{9}$ An act, desire, and behavior viewed or defined as religious is not situated in a vacuum, but is performed within a particular socio-historical context. Here, I investigate how the youth tried to situate their choices and acts as performance(s). I suggest that the available acts and performances that

8 Jenkins evokes the complex interlinkages between the individual's self-image and the external perception of her or himself: "That particular identity [...] is always a to-ing and fro-ing of how the individual sees herself and how others see her. These represent opposite ends of a continuum, one her self-image, the other her public image. Each is constructed in terms of the other and in terms of the individual's perceived similarity or difference to others. The difference is who is doing the perceiving, who is doing the constructing. This is the internal-external dialectic of individual identification" (Jenkins 1996, 52).

9 Religious agency, following Leming is "a personal and collective claiming and enacting of dynamic religious identity. As religious identity, it may include, but is not limited to, a received or an acquired identity, whether passed on by family, religious group, or other social entity such as an educational community, or actively sought. To constitute religious agency, this identity is claimed and lived as one's own, with an insistence on active ownership" (Leming 2007, 74). 
I view as apt religious performances should be understood as religious trajectories. I make use of the concept of religious trajectories in order to illustrate how individuals shape and fashion the structures they deal with in society, including the religious ones, and to indicate that their behavior and acts are simultaneously formed by these structures. This is important in view of the one-dimensional perception which assumes that youths' relationship to Islam has become individualized, and thus detached from religious communities and authorities. In contrast, I identify the processes through which a variety of religious performances are produced by pointing to the interaction between what is taught within the religious field, expectations from the group, and the subject's own multiple and contesting desires. By looking at available religious trajectories, I argue that youth create a variety and plurality of contingent subject positions in relation to these multiple discourses.

Not all actions or utterances made by a Muslim can be situated within an Islamic discursive tradition..$^{10}$ In order to be a Good Muslim in everyday life, it is important to be able to make the distinction between the acts and utterances that can be legitimated as Islamic, and those that cannot. In the everyday life of Muslims, the effort to be a Good Muslim who follows Islam (as a discursive tradition) is also about acquiring a skill. I see religious trajectories as encompassing a variety of social acts that are made acceptable as religious acts or practices within a religious social field. Thus, I am concerned with behaviors that strictly speaking seem to not completely fulfill or reproduce the religiously defined norms, but the performance of which are nevertheless made acceptable, or at least tolerable, as religious acts.

\section{Trajectories of Religious Acts}

Focusing on different trajectories of religious acts and behavior allows us to talk of Muslim religiosity as individualized, negotiable, and as providing opportunities for creativity. At the same time, it makes it possible to avoid falling into the trap of dismantling the relevance of existing strictures or

10 Asad contends that "even where traditional practices appear to the anthropologists to be imitative of what has gone before, it will be the practitioners' conceptions of what is apt performance, and of how the past is related to present practices, that will be crucial for tradition, not the apparent repetition of an old form" (Asad 1986, 15). My aim here is to make use of ethnographic material in order to examine how Asad's mainly theoretical argument works in the everyday life of Muslims. 
religious discourses within which the youth situate their agency in order to be perceived as particular kinds of religious subjects. It is the Self that brings the religious rules into life (Cohen 1994, 50). Religious rules and norms are pursued or performed by different individuals in different ways at different times. However, it does not follow that such variety of actions is religiously incorrect or religiously flawed. Rather, whether or not an action is religiously proximate depends upon how it is situated-by the actor and socially relevant others-in relation to the religious discourse provided by the social field.

In what follows, I present four different trajectories for defining an act, behavior, or desire as religious: "effort," "exceptions," "contesting knowledge," and "the use of multiple references." This is not intended to represent a complete range of possible ways to interact with religious knowledge and social surroundings, but rather to illustrate available trajectories of religiously defined acts. I emphasize that these categories of social practice are neither mutually exclusive nor temporally or contextually distinct.

\section{Trajectory 1: Effort}

The aspiration to "stay on the straight path" is ridden with several challenges for the youth in Berlin. These are reflected in concerns voiced by individuals during meetings about not being able to perform the five daily prayers, losing patience with a younger brother, or listening to haram music. One way to justify the failure to live up to the religious norms is to demonstrate that an effort was made. In the following conversation between Fatima (31) and me in her home, Fatima talked extensively about the importance of effort:

"Many young Muslims in Germany try to do everything perfectly," Fatima explained. "It can be too much for someone, you know. They set the goals very high. I therefore try not to set the goals too high. Like one sister in MJ in Stuttgart was from a very strict family and started in MJ. She was very concerned that we be correct, wondering why no one in MJ used a long coat, for example, which we should. She was very (insistent) that we should be correctly dressed. And then one day she ran away from her parents' place, started to wear (Western) clothes and make-up, and took her headscarf off. No one understood why. Then, I met her in the street, and since I have been taught that we should be tolerant and try not to judge, I asked if we should sit down for tea. And then I asked her; she used to be so concerned that we should dress properly and such [why had she suddenly changed]? And she said that we will never manage to live like hundred percent correct Muslim anyway! 'But we should at least try', I replied." Fatima continued with the 
story of her brother. He wore a beard for a long time, she explained. "When you are a Muslim you should have a beard, like Mohammad, it should be two centimeters long. And he had like, all around (his chin), but not long. And then after the divorce he took it all off, he shaved completely." When Fatima asked why he had shaved it off, he said, "well, the one before wasn't hundred percent Muslim either!" Fatima maintained that many feel that they must either practice Islam correctly or not at all. "They forget that they are human, that they should try as much as possible. Always improve themselves, knowing that they can never be perfect." She insisted that to her, "it is a matter of trying, to continue to try the whole time! (...) They are so strict with themselves, although it is difficult."

A little later, she related that, "there is this silly story, a story of the woman who could not pronounce the letter ' $\mathrm{H}$ ' in Arabic, and so instead of saying Herif ("Man" in Turkish) she said Alif all the time, and so when she died she had this word on her mind the whole time, 'cause she had tried so hard correcting it. And then in front of Paradise she was asked who is your book etc. and then she was saying this word the whole time, but then Allah said 'It is fine, send her in.' 'Cause she had made the effort - that's what is the most important. Effort." She continued, "we have the alarm clock on for the Morning Prayer." Her husband always got up, but she did not always manage to get out of bed. At those times, she would think, "ah, when I didn't wake up, then I don't have to do it [the prayer], 'cause sometimes Prophet Muhammad slept in and then that was ok. And also in the beginning with [her infant] I often couldn't do the night prayer. That was too hard. (...) But he [her husband] always thinks that I am terrible, so lazy. He always gets up; always reads one page of the Quran every night. I try, but then after one, two or three days, I can't anymore. But I make an effort, at least." She added, “I am always too late; when praying at the meetings, it's always, 'where is Fatima? Get her out of bed.' And I, half tottering, hurry to get my clothes on. Hopeless." She laughed.

The youth often admitted to neglecting to get up for the Morning Prayer or passing over the prayers during the day. Whereas the behavior of Prophet Muhammad is the ideal, Fatima called attention to the impossibility of completely living up to these ideals, reasoning that as humans they cannot possibly be as perfect in their religious performance as the Prophet. Fatima positioned her brother's beard within a religious discourse. Many Muslims consider that the beard, in a similar shape as the Prophet wore it, is a sign of virtue. ${ }^{11}$ At the MJD presentations, the Prophet was portrayed not only

11 The status of the beard is disputed among Islamic scholars. In recent years the beard has not only considered as a sign of virtue, but also as a sign of Muslim conservatism or fundamentalism (Fadil 2008, 153). A Muslim journalist who I met in Berlin suggested that the style of a man's beard can indicate a range of social meanings, including whether a person is fundamentalist in his belief, merely religious, politically oriented, or just likes the beard. 
as a role model, but also as the perfect Muslim. Furthermore, Fatima's reference to the young woman in Stuttgart demonstrates that it is sometimes best to modify one's cultivation of the moral codes since being too strict can lead to the other extreme, namely being discouraged and abandoning everything. Failing to live up to ideals and to perform all one's religious obligations can be partly excused by referring to effort. The sign of an effort demonstrates that the person is motivated, and that the failure to perform the ideal is not about unwillingess, idleness, or carelessness. ${ }^{12}$

\section{Trajectory 2: Exception}

Sometimes young people pursue social behavior that is not considered Islamically correct within their religious community, but which they try to legitimate by arguing that "they do it like that" or "it's like that with us." As the following anecdote demonstrates, customs and social behaviors in their daily life, and during special occasions like weddings, were sometimes situated within cultural or ethnic discourses:

A 16-year old girl from Bosnia told me that she kisses her cousin on the cheek when greeting him. She said that kissing one's cousin on the cheek is not religiously correct as he is a potential marriage partner, a topic that the MJD weekly meeting some weeks earlier had dealt with extensively. Yet, she added that this is not so bad, "cause in Bosnia we are not allowed to marry our cousins anyway. It is [true] that in Islam you are allowed, but with us, it is not allowed. I grew up like that."

Furthermore, marriage celebrations and henna parties (engagement parties) sometimes comprise a mixture of religious, cultural, and traditional elements:

In the course of a conversation, three young women (16-19 years old) laughingly declared that they wanted certain celebratory elements in their weddings, like "this last girl's night out, which Germans do" or "I would like to have this tradition that you are carried around the village." A moment later, all of them added that they know it is "about tradition," and "not Islam," but that they would still like to include these elements.

12 This is in sharp contrast to the women that Mahmood (2005) discusses in her ethnography. She found that the most common answer was that a consistent failure to perform the five prayers regularly (which I must add was not the case with Fatima) will result in being sent to hell in the Hereafter. She also discusses a situation where the women argue that the failure is linked to the "vigilance with which one conducts one's daily affairs and the effort one exerts in orienting these towards securing God's pleasure" (Mahmood 1998, 110). However, the idea that the desire to pray must be cultivated and created is present both in Cairo and in Berlin. 
By displaying knowledge that certain acts or desires are not correct or based on Islam, the women legitimate these behaviors or desires within the religious social field. In this process, the individual confirms her knowledge of the distinction between pure Islam and tradition or culture by simultaneously stressing that "we do it like that" where "we" are the ethnic social field. I suspect that many youth felt the need to verbally emphasize their knowledge that a certain habit or tradition is not from Islam in order to present themselves as religious subjects who take the distinction between a pure and cultural Islam seriously, even if they decided to perform it differently.

Another common way that incorrect actions were rationalized was by confessing to being "too weak" and, once the illicit activity had concluded, performing a ritual wash (wudu') in order to "come closer to God again" or become religiously clean:

I visited Ines (20) in her home and we listened to German hip hop and pop music, including Xavier Naidoo, in her room..$^{13}$ She confessed that, "it is a sin to listen to such music in Islam, but I am too weak. I have to listen to it sometimes." She added that she would need to do wudu' afterwards, because there were so many bad words in the song.

The ritual wash wudu' is normally performed when a ritual impurity (hadath) has occurred, and before praying. According to Islamic belief, impurity is a condition brought about in a variety of ways, including morally neutral and biologically unavoidable acts, such as falling asleep or going to the bathroom (Murata and Chittick 1994, 13). Here, however, Ines talked about performing wudu' in order to become ritually pure (tahara) after a specific emotional and moral state, which could close the gap between doing an act which made her feel like she was straying away from God and the correct state of being.

At times, silence or the attempt to hide failures or flaws was seen as the best way to deal with erroneous behaviors. Samira (18) told me that the reason she was so silent during the meetings was because she was afraid to say something that might "not be correct." The desire to present oneself as a good Muslim and to be accepted as a worthy member of this community of practice can lead to impression management tactics, like withholding information about one's private life, which could appear to contradict the norms valued within the group. Impression management is particularly

13 Xavier Naidoo is a German singer and songwriter of South African descent whose style includes soul, R\&B, and hip hop. 
important for newer members who may not yet have achieved the skills, knowledge, and piety that provide symbolic capital within this social field. Activities that are not considered religiously correct were not always talked about or justified, but merely performed among trusted friends who were not going to evaluate each other according to the ideals they were obviously breaking, as in the following example:

On the way to one of the yearly MJD summer camps held in south Germany, the brothers sat at the front of the bus, and the sisters sat at the back. One of the girls (17) said quietly to her close friend and me, "that's where we should be sitting, where Fadwa and Leila are sitting!" [They were sitting on the first row of women after the brothers]. "We could amuse ourselves with the boys," she whispered jokingly, pointing to one of the boys, "nice ass, I want to take a picture." But she had to do it without the other girls noticing and ultimately she failed, since someone was constantly standing in the way.

Being close friends, the two girls trusted each other (and me) not to judge or talk behind each other's backs about what would be considered irreligious behavior. In this space, the youth differentiated between individuals in the group, and some of the women were considered stricter than others. Consequently, not every woman was invited to all home parties and some of the more outspoken youth tended to be less blunt in the presence of women whom they considered more serious or strict. The joke Nadia told during the Aquiqua celebration in the VICUM hall (see the introduction to this chapter) demonstrates that the youth try to judge whether or not someone will find certain behaviors acceptable or even amusing, and this can become a test where one risks losing face. That said, sharing one's weaknesses was also part of the meetings, as discussed in chapter 4, although few talked in detail about the stages of their lives prior to their having started to actively practice Islam.

\section{Trajectory 3: Contesting Knowledge}

Contesting knowledge is a religious trajectory where one casts doubt on whether an utterance or action is actually true or religiously defined. As such, one challenges the obligation to relate to the practice or custom in one's own daily life. Most of the time, the youth referred to religious authorities and sources when they argued for or against a statement or practice. As there is room for different interpretations within Islam, this frequently caused internal discussions, but such disagreements did not constitute a dismantling or individualizing of Islam as a discursive tradition. On the contrary, as Asad contends, "argument and conflict over 
the form and significance of practices are [...] a natural part of any Islamic tradition". The following event illustrates the negotiations and internal discussions present within the religious community:

During the annual three-day summer camp in 2004, several of the Berliner youth and I attended a seminar on "Women in Islam," which was only open to female participants. A woman in her late forties, together with a female German convert in her sixties, were invited as experts to discuss concerns particular to young Muslim women. After a short presentation in a room crowded with around a hundred listeners, the floor was opened for questions. One of the youth asked whether she could use tampons or not before marrying. The elderly woman claimed it would be better if she did not, because the tampon could harm her hymen. Protesting openly, Janna (19) argued that it should not matter whether the tampon damages the hymen, since the hymen should not be important in itself. Rather, Janna argued, the actual importance of the hymen is that one should not have sex before marriage, and this was a thing between each individual and Allah. The older woman agreed with Janna, but maintained that if the tampon destroyed the hymen, there would be difficulties in proving her virginity to the family and the husband. Janna responded that if her husband-to-be did not believe her when she said that she had not had sex before marriage then she would not want to marry that guy anyway! The discussion ended without agreement among the women.

The women understood and accepted that the MJD space was open for debate and disagreement, and that consensus did not have to prevail. This controversial conversation is only one example of discussions, negotiations, and disagreements within the religious space. Here Janna, a younger woman, dismissed the older women's knowledge as unacceptable. Janna was particularly outspoken, self-confident, and reflexive, and openly contested generational hierarchies. Furthermore, Janna did not defer to age as the marker of authority in religion, but contributed her own style of argumentation reflecting her knowledge and personal thoughts on the matter. In following the youth over a longer period of time, I noticed an increase in confidence in their own abilities to answer questions or put forth arguments as their knowledge of religious norms progressed.

In this critical intervention, neither Janna nor the elderly woman referred to religious sources. Janna ultimately rejected the importance of physically proving to outsiders whether she had complied with the religious duty of abstinence before marriage, as she saw this as a personal religious obligation, and her individual duty to fulfill. Janna did not deny that having sex before marriage was incorrect from an Islamic point of view. She did not contest the principle of virginity, nor did she argue for gender equality in terms of extending the same rules regarding intercourse 
before marriage to men. Rather, she challenged the older woman's ideas about how this principle should be implemented, along with the assumption that she should physically prove her virginity by keeping her hymen intact. Her critique was directed towards the idea that she had to prove she had not had sex before marriage to her future husband and his family, as well as to her own family. To Janna, this was a matter for her own conscience, and ultimately a matter between herself and Allah.

This conversation illustrates the general individualization of religiosity, which scholars have previously pointed to (Roy 2004). However, this individual reflection is mediated through broad religiously defined arguments. Thus, it points to how disagreement can exist without this meaning that each individual produces their own singular, or individualized, line of Islamic reasoning.

\section{Trajectory 4: Using Multiple References}

One result of the increased religious education, familiarity with the canonical sources, and emphasis on self-reflection and personal duty in Islam, is that the young women are empowered to actively pursue religious behavior and to argue against certain perspectives. Self-reflection and an understanding of the texts become part of being a Good Muslim. When explaining to other Muslims why they dismissed a particular religious practice, most of the women referred to religious authorities in their explanations. The following event illustrates this:

During an MJD weekly meeting, three girls and I sat outside in the bookstore while the others prayed in the main room. Alesha (15) offered us sweet gummy bears from Haribo as Latifa (17) asked skeptically "are you eating that? Isn't there gelatin in it?" Alesha seemed to have been expecting this question and told Latifa that it is fine, "cause it has been through so much processing." Latifa took the candy bag from her and read on the back of it. She said, "here it says gelatin." "Yes", Alesha answered, "me and my sisters didn't eat it for a long time, but in the past few weeks we started eating it again. 'Cause we asked a sheikh [Islamic scholar] about it, and he said that 'cause it is so processed, it is not really pork anymore." She agreed that it was debatable, but she ate it anyway. "Don't you want some?" She again offered the bag to Latifa, who was reluctant. "I don't know," Latifa hesitantly replied without taking the candy, though Alesha reassured her, "it's so good! We've been eating them again for three weeks. And my mother was like, 'are you sure that it is not haram'?" They had reassured her that it was not.

Alesha's older sister, Hamida (17), joined us and confirmed that they had started to eat Haribo again. "'Cause we asked a sheikh and he said that it is so changed in the mix that there is no pork left in it," she added as an 
explanation. "That means that you can eat all gelatin," Latifa commented, half doubting and half questioning. Alesha clarified, "yes, when it has been processed. We have been told that it is ok, 'cause it is so processed. We didn't just ask one sheikh, but several. Do you know the sheikh [his name]?" Latifa nodded. Alesha added, "he says that we are allowed to eat it." When Latifa commented that Green Palace, where they were standing, also sold gummy candies without any gelatin, the two sisters contended that, "it is so expensive!" The conversation drew to an end as we were called into the main room to start with the day's presentation.

Although there seems to be much individual self-reflection and perhaps even some pragmatism in this situation, Alesha and Hamida referred to an authority (a sheikh) when justifying eating Haribo, which was generally considered haram among the youth. Rather than considering this as an individualization of religious practices, I understand this type of practice as an individual reflection around what to dismiss and what to accept, which has to be situated in relation to a particular rhetoric. The two sisters explained their action by referring to religious authorities in order for their action to be viewed as legitimate within the religious social field. This argument partly reassures the Self, and partly confirms for others who are evaluating the behavior that the action is religiously correct. Acquiring familiarity with the religious sources and the variety of ways to make legitimate arguments improves the youths' comprehension of which actions are or can be made acceptable, their rights and obligations, and the possible scope for creative action.

Notably, by the end of the conversation, Latifa no longer contested the sisters' actions, but at the same time she did not help herself to the Haribo. Latifa might accept Alesha and Hamida's reasons for their decision, without accepting or trusting it as legitimate enough to guide her own actions. This exemplifies both the possibility for different interpretations and interactions with the religious rules, but also the necessity of situating one's decision within a particular form of argument.

Among the youth, I noticed that what could be viewed as an individual orientation towards certain religious ideals was nevertheless frequently situated within Muslim tradition through certain styles of argumentation. For example, while on our way to a park for a picnic, I walked down a street on a summer day with Nawar (17) and Somaya (17):

The two young women talked about how to dress for the celebration the day after, including what color of dress and shoes they were going to wear. Nawar turned to Somaya, saying, "you can wear the same color of socks as your sandals. That's what I usually do." Somaya told Nawar that she doesn't use socks in her sandals, to which Nawar exclaimed, "sandals without socks is 
haram!" Somaya said, surprised, "what? I have never heard that before." Nawar explained, "yes. Once I went out without socks in my sandals, barefoot, and then my brother said, 'Hey, what are you doing, that is haram." Somaya sighs, "sorry, hey, but I am not doing that, I have so many sandals. I just bought a new pair." Then Somaya asked which school of Islamic thought permits not wearing socks, and said that she would follow that school of law on this issue.

Although at first nonchalantly brushing aside the correction by Nawar, Somaya followed up by asking which school of religious law she could follow in order for her action not to be religiously flawed. Though this might seem like a banal example, my point is that Somaya's choice to not wear socks can become religiously acceptable by referring to a school of thought that makes her action religiously legitimate. ${ }^{14}$ What at first may appear as an individual practice is, by reference to Islamic law, again situated within a religious framework.

Mass education, Eickelman and Piscatori (1996, 111) contend, has opened up the interpretation of religious texts and authorization. Access to knowledge has created new spaces of religious contestation (Mandaville 2000, 283), and youth learn religious arguments to support their choices and comportment. There are, of course, limits as to which exceptions will be deemed acceptable within this religious community in Berlin. It is difficult, or probably impossible to legitimate eating pork, drinking alcohol, or openly having a sexual relationship outside of marriage. Further, listeners or viewers do not uncritically accept reference to a religious rule in a discussion or presentation. Perhaps paradoxically, the new spaces of religious contestation simultaneously increase the need for authoritative sources. ${ }^{15}$ Muslims compare answers provided by different schools of law, and interpretations provided by different Islamic communities. By increasing their knowledge, the youth can compare religious interpretations and choose between them, which partly strengthens their moral autonomy.

There are certain rules and customs in Islam that the majority of youth did not wish to implement in their lives. For example, the fact that it is permissible for a man to have four wives in Islam was an issue that was often raised when debating the position of women in Islam. There are ways to deal with this principle without rejecting or contesting it, thus

14 Notice here also the role of Nawar's brother in guiding and ultimately forming Nawar's behavior.

15 Thus, as discussed briefly in chapter 4 , the idea that an increase in literacy and objectified consciousness reduces the need for young people to turn to religious authorities to make sense of their religion must be modified. 
without promoting spiritual cherry-picking, but also without feeling obligated to personally implement it. The following discussion about wives in Islam at an MJD meeting illustrates potential ways to deal with controversial themes in Islam:

It was a very warm summer day and it had been warm the whole weekend. I sait on the subway on the way to an MJD meeting, reading a book, as Ismail (16) came over to me. She kissed my cheeks and sat down on the plastic seats. She was tired, she told me, as she had just been sleeping on the $S$-bahn (subway) and also because she had not sleep much over the weekend, having spent the night in the mosque for the Qiyam (the Night Prayer). ${ }^{16}$ She recalled the school in Egypt where she spent two years, and how the teachers would punish her when she was tired. As we walked along the street towards the MJD location, we saw Leila (21) standing outside the door. "Wow," Ismail exclaimed when seeing Leila's motorbike. Fascinated, Ismail wanted to sit on the motorbike, which Leila had acquired from her brother. Leila was going to take her driving test soon, and she told her, "you have to do a lot of du'a for me so that I pass the examination of the driver's license." Fadwa (23) arrived in her car with ice cream. Since it was the last day of school the following day, she had thought she would not do the regular program. "Have you prayed?" she asked. They conducedt the prayer together, after which the youth read from the Koran. A younger girl, Alesha (15), did not want to read a sura from the Koran for the second round, "'cause the sura is too long." Fadwa suggested that she share it with Ismail. She will recite half of the sura and Ismail the rest. Alesha was finally convinced and read it. Afterwards, she continued by reading the German translation.

People were tired and not enthusiastic, and Fadwa tried to be ironic to ease the atmosphere. She then talked about the Qiyam in the mosque that weekend, where there had also been a nice presentation: "You missed something," she said. Fadwa continued talking about the Sunday presentation, which had been about the wives of Prophet Muhammad. "Fatima was the most loved child of Prophet Muhammad and it was like when she was sad, he was sad and when she was happy, he was happy, and that only by seeing her, he forgot everything. And then it was asked whether it is like that with us today-whether we forget everything when we see our mother and father?" She continued to talk about having more wives. "It is after all allowed in Islam. But there are certain conditions; that the man is strong enough to economically provide for them, and that he is able to treat them equally." The girls stressed this aspect and many expreseds doubts that a man would be able to treat his wives equally. Leila inserted, "there are occasions when the wife also prefers the arrangement. (...) The sheikh was talking about that in the presentation yesterday. And he said that the Europeans criticize the

16 Literally: "standing." The reference to Qiyam here implies to spend the night together with other Muslims, usually in a mosque, reading the Quran, listening to religious presentations and praying the Qiyaam al-Layl (the voluntary "night prayer") together. 
Prophet Muhammad a lot, saying that he married so many women, that he (liked women a lot). But it wasn't like that. When he was 25 years old, he married a woman 15 years older than himself! And then, 25 years later he married the next! And he still really loved her the most, even if she was older."

Hamida inserted eagerly, "the Europeans always criticize the Prophet, 'cause they misunderstand it [his marriages]." Fadwa agreed, "and he [the sheikh] was saying that many men have more than one woman anyway-that they have at least a wife and a lover. Many have four wives anyway: one they have a legal contract with [being married], one secretary, one for the evenings and one for the weekends." Some of the girls laughed. Leila argued, "sometimes it is really better! Some prefer it. After war and catastrophe, there are more women than men, and instead of these women becoming prostitutes and having children outside marriage, it is better that a man marries them and they get support like that." Fadwa turned to Alesha, who was frowning, and told her, "you should not look like you think it is disgusting, don't be so one-sided about it. You have to think broader than that. Marriage is more than only that [sex]. There are a lot of aspects to marriage. (You should think) that the ones who are able to have more than one wife have come further [in their thinking], they have managed to think higher. It is also like a duty to take on an extra wife, so that she (will have a decent life)."

Amal (22) disagreed decisively, "yes, but then. It is not always like that! My husband [who is an imam] was once in Italy and there the men were all talking about having a second wife, and were all very excited about it, looking at the young girls. And then my husband, he was their imam, said that if you want to do your (duty), then there is this woman, she is a widow and alone and she needs someone. Who wants to marry her? And then none of the men answered-then suddenly they were not so eager." Fadwa agreed that men do not always think correctly about it. Leila argued, "it is like that in Islam, it is part of it and it is allowed [to have four wives], and we have to accept that it is like that. Allah has made (it/us) like that. But it doesn't mean that we have to accept it."

Amal emphasized that it is problematic in Germany, "'cause it's not allowed, and so only one woman can be registered, and then you cannot treat all your wives equally. Like one of them will not be legally married, and the children will not receive (child benefits)." As a result, Amal continued, one of them would live without legal status. Hamida asked whether it would be possible to write something in the marriage contract about this. Fadwa responded that she did that when she got married. Before the wedding, she talked with her husband-to-be and said that she would not like it if he wanted more wives. Hajja (23), who recently married an imam, now added, "me too. Like respectfully. I said that I know it is allowed, and I respect that, and if you want to do that, I accept that, but in that case, I am not in." Amal joined in, "I also talked to my husband about it before, that there was no way that I would accept that!"

Notably, Fadwa stressed that men are allowed to have more wives according to Islam. She actively tried to make the younger ones understand and 
accept this element of Islam, which is frequently criticized by nonMuslims and is a point of contention for critical voices against Islam. At first, I was surprised that Fadwa, who has grown up in Germany and has a university degree, so readily accepted this part of Islam. Yet, their answers exemplify how their style of argument relates to Islam as a discursive tradition, while at the same time refusing to incorporate certain Islamic practices in their daily life. Significantly, Leila and Fadwa acknowledged that polygamy is allowed in Islam, and thus did not hold the position that one can simply reject what one disapproves of. None of the women questioned the validity of the religious norm, and they all viewed the critique of the Prophet on the part of Europeans as a misunderstanding of his actions and the ideal behind polygamy. Yet, later in the discussion it becomes clear that Fadwa would never accept this religious custom in her own life. As her own actions demonstrate, the norms do not prescribe that the young women must accept polygamy in their lives. Notably, all of the married young women in the room, two of whom were married to imams, had written into their marriage contract that they would not accept a second wife. All of them advanced this claim without contesting the actual right of the man as provided by Islam, but instead focused on their own personal unwillingness to accept this practice in their lives.

During the debate the women also asserted that the legal reality in Germany renders it impossible to follow all the Islamically defined restrictions and obligations for polygamy that could make it religiously correct (meaning treating one's wives equally). Notably, none of the women expressed sadness or regret that polygamy is not allowed in Germany, but rather seem to happily accept this German law. Thus, drawing on a wide range of religious knowledge and rights opens up possibilities for excluding certain religious customs from one's personal life, without contesting Islamic norms.

\section{Pluralization of Religious Acts and Behavior}

\section{Alteration of Acceptable Performances}

The authority of practices and utterances in MJD were contingent on the youths' relation to more general authoritative discourses. Certain imams, preachers, and scholars were more admired than others in the youths' search for religious direction. Seeking answers for actions in their life, the youth would sometimes ask more than one authority in order to hear different opinions. New experiences, authoritative information, or age could 
to some extent alter their perception of what was acceptable behavior. According to Julie (28), Aishegül (31), being one of the elders and considered to be highly knowledgeable about Islam, played a prominent role in shaping ideas concerning male-female friendship among MJD participants. Julie recalled that at one point, Aishegül had said it was not Islamically correct to have male friends. However, at a later stage I overheard the following conversation between Aishegül and Somaya (17):

Somaya explained to Aishegül that she had come to better know one of the brothers during the MJD Paris trip. Aishegül responded that it is good that they should also get to know the brothers, "'cause they are also our sisters and brothers." Aishegül continued by saying that she used to think that one could not be friends with the brothers, but then she asked an Islamic scholar and he explained that it was not necessary to be that extreme. As a rule, she had stopped talking to brothers when the conversation became personal, since she didn't believe that was right. The Islamic scholar had told her that "it is allowed to be friends and to talk, as long as it is done in the right way and at the right place." Somaya asked, "For example where?" Aishegul thought about it and was hesitant, "I don't know. Not in a café, 'cause people can see you and think that there is something between you. Perhaps in a mosque, I would think. Hmm, no....” Aishegül changed her mind, adding that even more than a café, the mosques can be a place where people will think that there is something romantic between them. Finally, she said, "I don't know. It is for sure ok to call to chat and if you need help or something."

Aishegül modified her perception of what is acceptable by talking to several imams, which led her to change her understanding of what is most correct. The internal diversity of religious authority in Islam makes it possible for practicing Muslims to choose among different interpretations (Yükleyen 2007), without this process entailing a fragmentation of Islam. Importantly, within this religious community, Aishegül's considerations of which interpretation should be followed matter, because she is older, has a high level of religious knowledge, and is viewed as pious. In sum, Aishegül's reputation represents a symbolic capital that endows her vision of the social world with some authority. Noticeably, Somaya accepted Aishegül's reference to an Islamic scholar (without asking for the name) and Aishegül's evaluation of this knowledge as valid. In other situations with peers or less knowledgeable youth, I often heard Somaya inquire about the sources of knowledge before she accepted or dismissed a statement as religiously valid. The German convert Julie suggested that religious knowledge is often received more uncritically when it comes from someone with a Turkish background than when it comes from someone 
with a German (a convert) background. My impression is that in this space the binding power of religious authority is not merely related to age, but is a combination of the sources used, the particular person's (perceived) piety, style of argument, and knowledge of the religious texts and interpretations. Competence in quoting from the Koran or referring to ahadith generated respect and authority, and sometimes brought discussion to a halt. However, more research is needed on the process through which youth in European cities come to see particular sources as authoritative. ${ }^{17}$

The latter part of the conversation shows that though Aishegül argues that it is religiously acceptable to have male friends, how this is conceptualized matters, as socially relevant others in the religious social field may still judge such actions negatively and not as apt religious performances. The difficulty that Aishegül had in finding a "decent" place where Somaya could meet someone of the opposite gender also demonstrates that personal intent is insufficient in deciding what social activities to perform; how (Muslim) outsiders (might) assess or judge one's social acts also matters.

\section{(Per)forming the Religious Self}

I would like to take my argument in a different direction. As this chapter has illustrated, the youth by no means reproduce all religious norms in their social practice. They demonstrate creativity in the process of crafting their religious Self. Are the presented trajectories acts that, when performed by these women, contest the norms or ultimately subvert them?

Even if power, discourse, and ideology shape subject positions, these forces do not control how individuals take up or relate to these subject positions at various times. Furthermore, they do not control how individuals engage in transforming discourses of power (Moore 2007, 41). Just as an individual's process of identification is a perpetually unfolding story, the

17 Who represents an authority for youth living in Europe and how this authority is established is an under-researched area of study. I believe that German public discourse exaggerates the influence and authority of the imams. See Caeiro (2005) who looks at Muslim religious authority in Western Europe as expressed via the production of fatwas (formal legal judgment or view in Islamic law). He explores how this practice forms and is formed by media settings, state institutions, intergenerational change and gender dynamics. The edited volume "Women, Leadership and Mosques" (2012) by Bano \& Kalmbach (eds.) argues that women base their claims to authority on a number of factors, including knowledge attained by formal religious training, a pious reputation, a charismatic style, family ties to religious leadership or education, and a dedication to religious outreach work. 
process of crafting the Self never comes to a halt. These trajectories show the possibilities for action available to religious subjects, where the intention is neither to challenge nor to alter religious norms. This should not be understood as merely an individualization of Islam; rather, it is a creative negotiation of norms and represents ways to resolve the tensions and discrepancies that make up daily life in Berlin. When situated within a religious group where one's actions and individual person are (un)consciously measured against religious norms, it becomes necessary to position one's actions within or in relation to how one ought to behave.

Rather than positing these trajectories of religious acts as resistance, we might examine them as creative bargains or subtle performances in subjects' "discursive strategies" (Kondo 1990, 227), where religious meanings are (re)appropriated and played out in relation to religious orthodoxy. This does not simply create a space of resistance, nor is it a repetition of norms. These trajectories demonstrate the possibilities for individual creative agency in a particular space, and as such, they enable individuals to situate themselves as religious subjects through what might appear as contradictions and incongruities. Furthermore, they indicate the various ways of crafting a religious subject and how the "doing of norms" is performed even when the youth are not stringently replicating the norms. These various expressions of agency are positioned within the discursive field of norms and ideals, which consequently legitimate behavior as religious and the actors as specific religious subjects within a religious social field. ${ }^{18}$

A religious identity includes bodily enactments, which comprise "signifying practices" that are mediated through knowledge, exercises, reflections, and experiences. A religious subject may be individually selfdetermined and self-reflective, but the acting out of her religious Self must be understood as mediated through other religious bodies and the existing orthodoxy to which she decides to orient her religious Self. Through performativity, the individual continuously struggles to craft the Self in ways that move closer to the ideal religious subject, that is, moves closer to being religiously proximate. In this process the individual simultaneously

18 In this discussion, the question remains that "if ideology and power are not monolithic, if culture is not simply determining and if becoming a self is not simply a matter of socialization, of learning the codes of a particular cultural context, then what makes individuals identify with certain subject positions, and construct a sense of self through them (Moore, 1994; Ewing, 1998; Battaglia, 1995)?" (Moore 2007, 41). See Moore (2007) for an extensive discussion on this topic, in which she argues for the need to include the role of fantasy, desire and unconscious motivation. 
becomes part of and affirms her identification with a particular religious group. A Muslim identity is not a universal or substantive subjectivity. Rather, this work demonstrates that the youth are creatively crafting themselves, constantly becoming, in specific, located situations (see Kondo 1990). The performance of a "correct" religious identity needs to be learned and practiced without becoming automatic or a habit in a Bourdieuian way. The performance of this religious identity is, at the same time, the expression and formation of the Self.

As discussed earlier, learning to distinguish between culture and religion is one of the means through which the subject is constituted as a specific religious subject. At the same time, there are also elements of performance involved, as individuals frequently openly contest what is correct or not in order to show their proficiency in distinguishing between these two categories. This act is considered crucial in the crafting of the Self as a truthful or authentic religious subject. Inquiring about where a particular knowledge originates from reflects a process of self-reflection, and the individualizing of religious practice. However, when asking others where their knowledge derives from, the youth demonstrate the importance of being able to distinguish between culture, tradition, ethnicity and Islam. The references to religious sources when explaining what is allowed or not, confirms that the speaker knows this difference and that she recognizes the need to be critical of sources of knowledge. Furthermore, asking for information about sources before accepting the religious legitimacy of another's views is a way that women, in particular, position themselves as particular religious subjects. Through the MJD meetings, the youth acquire knowledge about how to become proper Muslims. This includes the performative aspects of being a proper as well as "correct" Muslim by providing what are regarded as religiously legitimate justifications for behavior.

\section{Individualization of Religious Identity?}

What impact does looking at the process of how particular behavior is legitimized have on the way we look at religiosity? Are we seeing an individualization of religion or an individual selection of religious norms? Several scholars writing about Muslim youth refer to an individual appropriation of religious tradition and a process of individualization. ${ }^{19}$ The so-called pluralism and individualization of religion among young

19 This is particularly the case for those writing about Muslims in France. See in particular Amiraux (2000), Babès (1996), Boubekeur (2004), Cesari (1998, 2002), Roy (2004) and Saint-Blancat (1997). 
Muslims born in European societies is commonly explained in terms of an increased secularization of the youth and the impact of the European social environment on the youths' religious identity. ${ }^{20}$ This view, I argue, fails to recognize Islam as a discursive tradition within which individuals seek to legitimate their acts or behavior as religiously apt or proximate. Furthermore, it fails to recognize that religious practices are rarely singular, individual acts situated outside of a religious social field, however near or far that religious field may be.

Clearly, Muslim youth who are socialized in Europe are presented with a variety of allegiances and ideals, including secularization and individualization (Klinkhammer 2003). Ulrich Beck and others have suggested that individualization in contemporary European societies include, on the one hand, "the disintegration of previously existing social forms - for example the increasing fragility of such categories as class and social status, gender roles, family, neighborhood etc.," and on the other, "new demands, controls and constraints [that] are being imposed on individuals" (Beck 2002, 2). ${ }^{21}$ Just like there has been a decline of communities based on class, status, and voting behavior (Lipset and Rokkan 1967), scholars have suggested that Christian religious communities are in decline. Davie coined the expression "believing without belonging," which characterizes "the persistence of the sacred in contemporary society despite the undeniable decline in churchgoing" (Davie 1994, 94). ${ }^{22}$ This process of privatization and individualization of Christian religious practices has consequences for the internal functioning of the religious sphere. It weakens both religious authority and the feeling of obligation regarding, for example, church attendance. Further effects of individualization include the lowering of social status, a reduction in the number of clerics, and the decline of adherence to moral values of sacrifice or discipline. This can also be seen

20 This includes in particular Amiraux (2000), Boubekeur (2005), and Cesari (2000, 2002).

${ }^{21}$ As a consequence, Beck argues, the "normal biography thus becomes the 'elective biography', the 'do-it yourself biography' [which] is always a risk biography' - a state of permanent endangerment" (Beck 2002, 3). Zigmun Bauman has likewise suggested that: "Nowadays everything seems to conspire against ... lifelong projects, permanent bonds, eternal alliances, immutable identities. I cannot build for the long term on my job, my profession or even my abilities. (...) togetherness lasts no longer than the gratification of one of the partners, ties are from the outset only 'until further notice'" (Bauman 1993, 17).

22 Grace Davie (1994) also coined the idea of "belonging without believing," which she calls "vicarious religion" in relation to Scandinavian countries where a large part of the population remain members of the Lutheran church without attending church services. Consequently, she suggests that religion is only performed by an active minority on behalf of a much larger number. 
through individual lifestyles in which self-realization prevails, people are more mobile, and there is a decline in inherited identities (ibid.).

One of the main outcomes resulting from the individualization and privatization of religion is a shift from religion imagined as a principle of heteronomy (which broadly means submission to governance by external control) to religion imagined as an identity and as supporting individuals in an increasingly uncertain society. The individualization of religious experiences of Muslims is meant to capture the idea that religious experiences have become personal and subjective in their endorsement and composition (Fadil 2008). The idea is that modern subjects decide whether to be religious, as well as when and how to be religious. Religious belief, then, is no longer fixed, but experiential and expressive.

As I have briefly discussed, the perception of individualization has also found resonance among scholars studying the Muslim population in Europe. It has been argued that the main style of individualization among the Muslim population in Europe is the attempt to unite personal freedom with the conviction of a type of transcendence defined as relative, meaning regulated in relation to the majority society's constrictions (Cesari 2005b, 5). Likewise, Amiraux (2003, 85) talks about the "feminization" of Islam in Europe, a situation in which Muslim women choose, assume, and assert faith. She argues that the practices are no longer "inherited," but are "reinvented" by their actors (ibid., 89). According to Amiraux (2000, 120), the individualization of religion among youth can be seen in the individualization of their decision-making. She perceives this to be a structural outcome of their daily social organization, the associative environment in which they are socialized, and the available modes of participation. ${ }^{23}$ Similarly, Roy (2000) suggests that in the plural urban space, Islam is largely an individual affair where the community is not given, but must be constructed and invented.

I agree with Amiraux (2003) that the decision to be a practicing Muslim is actively taken by the individual. Yet I contest the idea that the decision to identify with Islam is taken independently from other individual social

23 Amiraux recognizes that this development does not include a detachment from the collective, but does not problematize the continued complex social relation between the faith an individual claims and her or his faith in the community. However, she acknowledges that there is a lack of research on the question of individual processes of religious sentiment. The latter refers to how the individual ascribes meaning to a religious sentiment and belonging to a tradition, as well as how to formulate certain practices independently of what the community recognizes as legitimate (Amiraux 2003, 88). It is in part this gap that I aim to fill in this chapter, as well as chapter 4 and chapter 5 . 
positions. Clearly, religious and ethnic identifications are only two among several possibilities for identification, although perhaps the most readily available for these youth. In that sense, the act of practicing Islam and of crafting themselves as religious subjects is largely a matter of choice. ${ }^{24} \mathrm{To}$ some extent, the youths' emphasis on reflection and knowledge of the religious sources leads to an individualization of religious practice (or rather an objectification of their religious practice, as discussed in chapter 4), in that they become more autonomous in the process of judging their own religious actions. Nonetheless, the understanding of the religious practices of the young women in my study must be situated in relation to the rhetoric and ideals learnt in a group. Furthermore, although the youths' interpretation of religious belief might objectively diverge from each other, they share feelings of self-transcendence and concepts of faith. In addition, being critical of religious interpretations does not automatically mean a dismissal of key religious dogmas.

Still, much research on Muslim youth in Europe overemphasizes choice, autonomy, and detachment from religious communities and authorities. For example, studying young Muslims in France and Germany, Tietze argues that "the identification with Islam becomes an ordinary means, one among many, for the construction of subjectivity" (Tietze 2001, 294). The problem with seeing Islam as yet another aspect of individual choice is that it neglects the role of Muslim traditions in the early socialization of the individual. ${ }^{25}$

A closer view of the religious activities of youth in Europe who practice Islam within a faith community demonstrates that while there is a shift in the arrangement of authority, in that women and youth both attain and transform authority, religious authority as such is not eradicated. ${ }^{26} \mathrm{My}$ observation of the youth in MJD illustrates that the idea of a free-floating and rationally chosen religious identity does not hold. The youth in MJD do not sharply distinguish between their religious belief and orthopraxis,

${ }^{24}$ See especially Klinkhammer (2003), Nökel (2002), and Tietze (2002) who argue this for Muslims in Germany.

25 This kind of argument, Salvatore claims, "superimposes an allegedly traditional continuity within religious practice between bodily disciplines and gestures and their 'spiritual sense'" (Salvatore 2004, 1023). The process of change is simply ascribed to the social context of the youth. According to Tietze (2001), the youth often celebrate the end of Ramadan without having personally fasted. The religious meaning of fasting, she argues, is separated from the practice, bringing about a culturalization of Ramadan. This, Tietze claims, reaffirms the idea of a divergence between believing and belonging. Salvatore (2004) offers an astute critique of this line of argument.

26 This is suggested also by Amir-Moazami (2007), Nökel (2002) and Salvatore (2004). 
as some scholars (including Tietze 2001) do. The religious agencies of these youth are not the outcome of strictly individual choices, and do not mark a private Muslim subjectivity, but are situated vis-à-vis Islam as a discursive tradition. Recognizing the increase in individualization in the religious field, the French sociologist of religion Hervieu-Léger suggests that:

Modernity has deconstructed the traditional systems of believing, but has not forsaken belief. Believing finds expression in an individualized, subjective and diffuse form, and resolves into a multiplicity of combinations and orderings of meaning which are elaborated independently of control by institutions of believing, by religious institutions in particular. (HervieuLéger 2000, 74)

However, at the same time, Hervieu-Léger argues in "Religion as a chain of memory" that this independence is limited by the economic and socio-cultural positions of the individual, and hence that, "there is no religion without the authority of a tradition being invoked (whether explicitly, half-explicitly or implicitly) in support of the act of believing" (ibid., 78).

Hervieu-Légers (2001) suggests that the idea that religion is currently individualized must be modified in view of the need for (religious) subjects to be with others who verify their lifeworld and value orientation. In other words, modernity does not necessarily mean that a religious person no longer needs to invoke the authority of a tradition as a foundation for her or his act of believing. This authority need not be a physical local faith community in which one regularly participates, but includes online chat rooms, Muslim neighbors, family, and religious organizations in or outside of Germany.

One may wonder whether religious experiences have not always involved a certain individualized form. It is worth evoking Simmel, who in 1898 considered the dynamism of religion to be an incomplete process where the individual person relates to a religious tradition with degrees of durability:

One must bear in mind that religion, as a spiritual experience, is not a finished product but a vital process that each soul must create for itself, no matter how stable the traditional content may be. It is precisely here that the power and depth of religion are found - namely, in its persistent ability to draw a given item of religious data into the flow of the emotions, whose movements must renew it constantly (...). (Simmel 1997 [1898], 118-19) 
Simmel positions the communication between tradition and the "flow of emotions" as a process through which the religious project is generated. ${ }^{27}$

Compared to the Catholic Church, with its clerical and hierarchical centralized administrative structure, Islam, at least in its Sunni branch, has always been structured in a more decentralized and egalitarian way (Casanova 2001). Without centralized institutions defining the authoritative doctrines, Muslims continue to act within an increasingly pluralistic, modern society in ways that are multiple, varied, and sometimes inconsistent (ibid., 29). Many scholars of contemporary Islam agree that there has been a process of pluralization and fragmentation of religious authority in Islamic tradition..$^{28}$ Rather than advancing the secularization of Muslims, this opens up and expands the terrain of religious education. Educated Muslims are given spaces-or construct their own spaces-in which to discuss Islamic tradition and how Islam is compatible with democracy, civil society and human rights. Such spaces tended only to be filled by Muslim intellectuals or the traditional ulama. For Casanova (2001), the creation of these new spaces within Islam reflects the broader movement of all world religions towards modernity, a process through which each religion repositions their own respective traditions in an attempt to fashion their own version of modernity. In Germany, MJD exemplifies one of these spaces in which young Muslims came together and decided to form a new religious group. Being situated outside the frameworks of the mosques, which they viewed as dominated by older, ethnically oriented leaders, provides the youth with different opportunities for constructing authority, enhancing religious understanding, and pursuing religious celebrations (Bendixsen 2013).

Furthermore, even if people draw upon religious tradition selectively, this does not destabilize the integrity of the religion (Asad 1993). Adapting a tradition in order to meet new challenges does not necessarily undermine the coherency of a tradition. The recognition of religious authority or the legitimacy granted to particular practices and utterances depends upon how an individual situates these in relation to authorizing discourses

27 It is this project, taken up individually and/or collectively, that Leming calls "religious agency." She argues that: "the actions and adaptations that people adopt, create, and refashion to express their religious sensibility both reproduce and transform the traditional resources of religious groups" (Leming 2007, 74).

28 Casanova (2001), Eickelman (1992) and Mandaville (2000) have suggested that there is a pluralization process regarding religious authority in Islam. 
of a more general order. ${ }^{29}$ Thus, the creative, religious practices performed by these young women are not a rejection of Islam as a discursive tradition. The coherence of Islam is maintained even within variations in practices (Asad 1986). Orthodoxy in Islam never completely establishes or predetermines social relations. It remains a pivotal and idiosyncratic relationship of power, where discourse and debates determine what is considered as correct and what should prevail.

The trajectories of young women in Berlin presented here are situated in plural, even creative, ways within Islam, without this being synonymous with the development of secularization or individualization. It also does not mean a decrease in the importance of situating one's religious acts visà-vis a faith community. Indeed, the young women specifically legitimate their behavior through references to orthodoxy and religious rhetoric. By examining how these youth practice Islam in their everyday life, I call attention to the need to distinguish between the religious as fixed beliefs or dogmas, and the religious as personal and collective practices situated in social life, where the social material setting has implications for subsequent interpretations and practices. ${ }^{30}$

Women who relate to a religious organization, a faith community, or a group, need to situate their actions within a religious framework, so long as they seek to be regarded as religious actors. This should modify the conclusion drawn by Nökel $(2002,67)$, among others, that women individually decide which religious forms to accept and Klinkhammer (2000, 286), who argues that women adopt a mode of individualization and rationalization in their orientation towards Islam.

29 As Ismail suggests, "in taking account of a discursive tradition, its continuity and evolution, one should be careful not to postulate some unchanging Islamic view or position on morality. A careful study of Islamic history demonstrates the existence of varying conceptions of morality and sexuality and also of a tradition of religious skepticism (Ismail 2006, 78)."

30 Ismail convincingly argues that, "in its interaction with the social, religion ceases to be religion (understood as fixed beliefs, dogma, immutable rites and so on)" (Ismail 2004, 620 ). She contends that this is not only the case in the modern or postmodern period, but that the argument has "meta-theoretical implications." This observation is supported by the distinction between "religion as faith," which brings with it personal and individual direct contact with the godly and "religion as a set of rules," which are interpreted and bargained upon in social settings. In the latter process, situational factors will have an effect on the interpretations and negotiations (ibid., 620-621). I believe that Ismail is here touching upon the limitations of Asad's framework of Islam as a discursive tradition. Namely, by remaining on a theoretical level, this framework cannot sufficiently illuminate the social practice of crafting a religious Self in a socially specific context where a variety of social forces are at hand. 
Although this book recognizes that the women in this study choose to situate themselves vis-à-vis religious ideals, which represents a set of norms, the young people who make this choice must relate to discursive practices partly defined outside of their control. Understanding the subject to be "compelled to act from within a set of norms through which it negotiates its sense of self," Butler $(2005,19)$ underscores that the agency of the subject must "struggle with the unchosen conditions of one's life." At the same time, the creativity involved in choosing how to interact with religious norms demonstrates the opening up of spaces for individuality and agentive decisions, outside of those acts that either comply with or reject the norms. The youth do not completely reproduce or subvert the religious norms, but they also do not dismiss or actively resist (most of) these norms. Mostly, they try to comply with the religiously defined rules that are taught in the various spaces of their religious community MJD.

The ways in which they legitimate their accomplishment or failure to meet religious norms can take different forms, as exemplified by the various possible religious trajectories. Through their education and position as self-reflexive, responsible actors, they draw on techniques to deal with the norms and ideals that are promoted within the religious field. The turn to a pure Islam and literal religious practice introduces orthodoxy into the everyday practice of Islam. Even if the youth situate themselves within a religiously defined orthodoxy, they remain reflexive and creative in their behavior, neither in a pre-given nor purely individualized way. 